\title{
The Naturalized \\ Gender Order Of Rock and Roll
}

\section{Introduction}

One of the most interesting social developments in the United States in 1956 was the behavior of hundreds of thousands of mostly white, middle class girls, who screamed, danced, and sobbed to the point of "enthrallment," "near-hysteria," "mass hysteria," or "pandemonium," according to several newspaper and magazine descriptions. Elvis Presley, with his 1956 national debut, was the chief cultural site for this type of youthful expression. While the mass media regularly characterized the young female Elvis fans as innocent, gullible, and easily manipulated by the "obscene" physical gyrations of a showman like Elvis, the president of at least one Elvis fan club suggested that teenage fans were more savvy than many adults would like to think.

In a December 1956 interview, Kay Wheeler, president of the Elvis Presley Fan Club in Dallas (reportedly "the first and biggest Presley club"), expressed her take on the meaning of her favorite rock and roll star: "Elvis is a living denial of the notion teenagers should be seen and not heard" (Masters 1956). The presumably older male reporter admonishingly described the fan club president's words as "rather frightening."

With hindsight, it is now easy to see that the polysemic rhythm and beat of rock and roll has indeed been a major cultural force in the lives of generations of teenagers in the United States. Thirty years after the rise of Elvis, Rolling Stone magazine editor Jann Wenner (1986) made what has become a rather typical summary of rock and roll's history: "When all is said and done, the story of rock and roll is the story of a sound. . . The sound comes to life as a vehicle to express a generation's restlessness. Rock and roll becomes a teenager's sanctuary from the adult world, a badge of identification with its own lingo" (13-14). 
It is often tempting to neatly package rock and roll's history as youthful assertion of generational identity, typified by the notion of a "generation gap," and the cultural transgressions of racial and class boundaries, typified by rock and roll's "hybrid" origins (see also, Lipsitz 1990). But the screaming teenage girls at Elvis shows in the 1950s should make us also consider the matter of gender in rock and roll. Has rock and roll always offered the same liberating experiences to women and men? Or, has rock and roll adopted socially prescribed roles for men and women, resulting in widely divergent, gender-specific experiences?

Simon Frith and Angela McRobbie suggest that rock and roll is indeed gendered, and that it "works with conventions of masculinity and femininity that situate both performers and audiences along clear gender lines: males as active participants, females as passive consumers. Musically, the distinction is marked by the contrast between 'cock rock' and 'teenybop'"(Frith 1990, 420; Frith and McRobbie 1990). Other research (Christenson and Peterson 1988) seems to empirically confirm these commonsense categories (also called "hard" rock and "soft" or "pop" rock), but, like Frith and McRobbie, offers little explanation for the origins of these divisions.

I agree with Frith and McRobbie that there has long been male domination in the rock and roll industry. But, I also argue that the gender lines have not always been so clear, especially at times when young women shaped early rock and roll as its undeniably active and passionate fans. The traditional gender order of rock and roll is not natural, but naturalized. The acceptance of rock and roll as a naturally masculine medium is possible only by ignoring the historical marginalization of the female audience of rock and roll.

This article first explores the social order of gender in the 1950s, when young white, middle-class teenage females transgressed the "normal" gender order of social life, becoming powerful subjects as the dominant fans of rock and roll. Second, the article discusses how America's social authorities publicly responded to these vocal teenage girls by linking the disruption of white, middle class society's gender relations to fears of possible trangressions in the social order of age, race, and class. Finally, the article investigates the nonnalization of the social order for rock and roll, which actively suppressed or marginalized women's experiences (as "teenyboppers"), while celebrating rock and roll as a cultural vessel for rebellious young white men. This masculinization of rock and marginalization of the female audience repaired the earlier rupture in the social order of gender caused by young white women's prefeminist contestation over sexual power in rock and roll, and set the terms for rock and roll's current sexual politics. 


\section{The Social Order of Gender in the 1950s}

In a January 4, 1954 Life magazine feature story, the headline described the era's teenagers as "The Luckiest Generation" ("Luckiest" 1954). With photos of industrious, well-groomed white teenage men and women from Carlsbad, New Mexico, the story celebrated that, across the nation, "Depression's babies tolay have the pick of high-paying jobs." With so many money-earning opportunities, the teenagers of the 1950 s became the most important new market for the Fordist economy of the early post-war years. A Newsweek "Spotlight on Business" story of 1957 bragged about "The Dreamy Teenage Market," consisting of "17.2 million citizens between the ages of 12 and 20 , with more than $\$ 9$ billion a year to spend" ("Dreamy" 1957, 94). 'Teen magazine announced its arrival in June 1957 as a publication "born into a generation that has finally come to recognize persons between the ages of 13 and 19 as a distinct cultural group" (Laufer $1957,5)$. Across the nation, retailers confidently extended credit to engage and habituate the young, lucrative market in the fast-moving consumer culture. By 1959 , when teenage consumers had become a $\$ 10$ billion annual market, Life magazine posited that "if parents have any idea of organized revolt, it is already too late. Teen-age spending is so important that such action would send quivers through the entire national economy" ("New" 1959, 78).

In many cases teenagers had indeed taken on the life of an adult while still in their teens. For teenage women, in particular, the culmination of high school was quickly followed by the culmination of single life. As new wives and mothers, young women played an even more important cultural and economic role in post-war America. In fact, the continued reproduction of young families with breadwinning husbands, domesticated wives, and status-oriented children had become crucial to the U.S. economy of the 1950s that was based on new suburban housing, automobile transportation, consumer products, market research, and the new mass medium of television (see, for example, Friedan 1963). As chief purchaser, the female homemaker served as the marketing object of these new nuclear family economic consumption units (Haralovich 1992; Coontz 1992).

The domestic role of the homemaker mother and the paternalistic, breadwinning father was celebrated and made normal through hundreds of print and broadcast ads, and in popular television shows such as The Adventures of Ozzie and Harriet (1952-1966), Father Knows Best (1954-1963), Leave it to Beaver (1957-1963), and The Donna Reed Show (1958-1966), illustrating Lynn Spigel's (1992) argument that "the fifties witnessed a nostalgic return to the Victorian cult of domesticity which was predicated upon the clear division between public and private spheres" (6). Given the circumscribed role of married life for women at this time, Ehrenreich, Hess \& Jacobs (1986) explained that "for girls, high school was all there was to public life, the only place you could ever hope to run for office or experience the quasi fame of popularity. After that came mar- 
riage-most likely to one of the crew-cut boys you'd made out with - then isolation and invisibility" (27). The high school years were difficult enough. With feminine success defined as a marriage of appropriate status and then motherhood, teen girls had to negotiate the difficult role of keeping marriageable boys sexually interested, yet preserving their virginity for marriage.

As Elaine May (1988) noted, America's sexual ideology during the Cold War was one of containment-sex made permissible only by marriage, with men as the sexually dominant breadwinners and women as the sexually submissive mothers. "Many believed that a violation of these roles would cause sexual and familial chaos and weaken the country's moral fiber" (117). The moral force of permissible sex only within marriage surely helped contribute to the crush of teenage newlyweds and a statistical milestone: the year 1956 marks the youngest age of marriage for American men and women in the twentieth century. The median age of first marriage for young women in 1956 was 20.1 years, scarcely beyond the teen years, while men, after perhaps exercising their socially permitted opportunity to "sow wild oats," first married at a median age of 22.5 (see U.S. Bureau of the Census, 1975). Into this sexually ordered world, where young white, middle-class men and women were promised they were the "luckiest generation," entered Elvis Presley and rock and roll.

\section{The Early Days of Rock and Roll: Transgression of the Gender Order}

Newly empowered as consumers, teenage girls in the 1950 s purchased products like teen-targeted clothing and cosmetics, and began their hope chests for their future married life, where they would soon serve as head purchaser for a growing nuclear family. Whereas most consumer products of the era were marketed in some way to enhance a girl's ability to realize the "feminine" American Dream of marriage and motherhood, rock and roll-an emerging teenage consumer product in its own right-offered a more malleable text for teenage women. Elvis became by far the most popular of a number of new rock and roll performers.

James and Annette Baxter (1958), in a remarkably prescient Harper's magazine article in January 1958, explained the popular appeal of Elvis Presley: "the gawky, loose-limbed, simple boy from Tupelo, Mississippi, was a genuine tabula rasa, on which the American populace could keep drawing its portrait, real and imaginary, and keep rubbing it out" (45). Bouyed by advertisers' frequent promises that one could be socially constructed and remade through consumption of certain products, teenage girls began to realize other possibilities through their consumer power. They could, with the polysemic qualities of early rock and roll, remake socially constructed roles for women, or at least experiment with the possibilities of alternative identities. 
Much in the same way that African-American women in the 1920s used the blues to reclaim control over their own sexuality (Carby 1990), white middle-class teenage girls of the 1950s found rock and roll music to be an important site to begin resisting the oppressively limiting structure of sexual roles that confronted them in post-World War II America. Robert Allen (1991), in his study of burlesque and American culture, offers a valuable framework for how power and resistance are enacted through seemingly apolitical popular culture:

In the cultural realm, groups in a position to do so rarely exercise their power with the force and directness suggested by the term "domination." Rather, power is expressed through ordination: that is, by attempting to regulate through the arrangement of things in ranks and orders - what is high, what is low; what is us, what is them. Every instance of discourse is itself an act of ordination, an articulation (both in the sense of uttering and in the sense of linking) of signifiers. Thus, just as there can be explicitly ordinative discourse, there can also be insubordinate discourse: discourse that trangresses or inverts existing orderings, discourse that challenges the notion of fixed orders or the ordinative authority of another discourse. (34)

Maintaining social order was a profound concern to many of the country's government and community leaders in the 1950 s, who were deeply concerned that "a whole generation stood poised on a moral precipice" of juvenile delinquency (Gilbert 1986, 15). ${ }^{1}$ Elvis, especially in the first few years of his career, became one of the most potent symbols of youth gone wrong. Of particular concern to the nation's moral authorities was the sexual implications of Elvis' act, and the fear-rarely directly addressed-that such rock and roll music would turn the impressionable, mostly female, teenage audience into sexual delinquents. For teenage girls, sexual delinquency typically meant sexual activity outside of the context of marriage. Of course, such control of young women's sexual thoughts and behavior was not just a concern during the 1950 s, but a recurring concern in twentieth century America.

Just two decades before the rise of rock and roll, the nation was focused on the potentially corrupting force of motion pictures on young women. Several studies were underwritten by the Payne Fund in part to investigate the effects of movies. One of these studies, Blumer and Hauser's Movies, Delinquency, and Crime (1993), a study of "sexually delinquent" girls, concluded that "passionate love pictures may act as a sexual excitant. In witnessing such pictures many of these girls experience strong sexual desires-sometimes of an almost impulsive character-which made them markedly receptive to advances by men" (81).

By the 1940s, concerns over female sexual delinquency had turned to the wartime problem of "Victory Girls," those teenage women who loitered around troop training centers, and engaged in what the American Social Hygiene Association surreptitiously referred to as "sex delinquency of a non-commercial character" (Gilbert 1986, 32). Senate Subcommittee hearings held in late 1943 and chaired by Florida's Claude Pepper concluded that working women, many of whom had left the home to fill 
defense industry positions during wartime, were the cause of their children's delinquency.

With concerns over the sex delinquency of young women during wartime, it is not surprising that some attributed Frank Sinatra's success to "a manifestation of wartime degeneracy" (Frazier 1943, 56). Long before Elvis was ever a star, women across the United States had formed "Frank Swoonatra Fan Clubs" (Frazier 1943, 55). Following the traditions of Rudy Vallee and Bing Crosby, Frank Sinatra was one of the few successful twentieth century American singers who enjoyed a period of great popularity with young female audiences. The last great crooner before the advent of the rock and roll era, Sinatra was a huge sensation by 1943 , when he was 25 and in his first year as a solo performer. Sinatra's popularity was evident in the reportedly thousands of fan mail letters he received each day, and the huge crowds at his shows. One holiday show at New York's Paramount Theatre ${ }^{2}$ drew more than 10,000 fans, and-even with 150 extra police on hand-resulted in broken shop windows and injured people when many frustrated fans were unable to get into the show. At another Paramount show, an observer noted that most of the Saturday morning audience belonged to "the bobby-socks brigade, age perhaps 12 to 16." The girls would shriek and applaud during Sinatra's performance, while "a few of them slump into their seats, either fainting or convincing themselves that they are doing so. Some of them rush down the aisle to get as close as possible to their hero" (Bliven 1945, 13).

Sinatra attributed his own popularity to his youthful style. "I wear bow ties, sports jackets and sweaters, and kids like 'em . . . I'm their type" (Frazier 1943, 58). Yet, even with his often shrieking and swooning young female audience, Sinatra was not considered a serious threat to the fabric of American life. Sinatra's performances continued the dominant traditions of popular male recording artists, performing Tin Pan Alley standards such as "You'd Be So Nice to Come Home To," "That Old Black Magic," "She's Funny That Way," "Embraceable You," and reportedly his most popular song, "As Time Goes By." Using Crosby as his model, Sinatra simply became the new Bing Crosby for the younger generation (Frazier 1943). Thus, Sinatra's music (romantic crooning) and persona (a happily married family man who supported the sale of war bonds) was not in conflict with the prevailing values of the time.

In the context of wartime, a bobby-soxer ecstatic over Sinatra's romantic vocalizings was far preferable to a morally delinquent Victory Girl. Although he might have been marginalized because of his Italian-American ethnicity, Sinatra's non-transgressive Anglo-American appearance in the early 1940s (his style didn't include the zoot suit, which had come to symbolize ethnic and working class delinquency ${ }^{3}$ ) and traditional musical stylings made him acceptable entertainment for middle-class lifestylethus part of an ordinative discourse.

A decade later, Elvis Presley became the new star for teenage girls. Like the Sinatra bobby-soxers of the 1940s, young women shrieked, 
swooned (or convinced themselves that they might), rushed the stage, and occasionally broke shop windows in the energized melee of large crowds. Yet, the prevailing adult reaction to Elvis Presley's rock and roll performances was rarely pleasant bemusement, and more often suspiciousness or outright revulsion. For many adults, Elvis symbolized the unraveling of American social order, particularly with the generation of youth.

The insubordinance of the new rock and roll music, as represented by Elvis, was the inversion of the race, class, and gender order. The musical style of rock and roll-which originated from a rich pastiche of sources, most notably rhythm and blues, gospel, country, black folktales and legends, and even children's clapping and rhyming games-foregrounded black and lower-class white "hillbilly" culture (see Lipsitz 1990). Like rock and roll music, Presley himself presented an ambiguous multitude of symbols, for which he could be loved or hated. He was considered hillbilly white trash from the south, but also a music and movie star, and an example of American opportunity and success. He was white, yet he dressed "black," and bought his loud, shiny clothes from Lansky's in Memphis, a store with a mostly black clientele (Ward, et al. 1986, 77). He looked like a delinquent, with his greasy long hair and flamboyant clothes, yet he proclaimed he read the Bible, and didn't drink, smoke, or swear. His music was aggressive, but he was routinely polite, and even shy, in interviews. He looked like a rebellious nonconformist, but he dutifully looked forward to his imminent military service (he reported to the Army's draft call on March 24, 1958), and requested no special treatment, even though the armed forces reportedly offered him his own company of men from his hometown, Memphis (Ward, et al. 1986, 163).

Given the ambiguities of Elvis' image, there was no denying the physical nature of his act, which was the chief target of moral outrage and routinely described as "burlesque" in some manner. Framing Elvis' act as burlesque was rather ironic, for the original American burlesque shows performed for middle-class audiences in the late 1860 s by Lydia Thompson and her company inverted the traditional bourgeois gender order of male dominance with ribald parodies and spectacles staged by female performers. But the "burlesque" that Elvis' critics referred to were the marginalized and non-subversive theatrical shows for working-class men from the turn of the century through the 1930s that featured voiceless female performers engaged in the purely sexual display of cooch dancing, the shimmy, and the striptease (Allen 1991).

According to Robert Allen (1991), "the cooch dance linked the sexual display of the female performer and the scopic desire of the male patron in a more direct and intimate fashion than any previous feature of burlesque. Here, all pretense that the performance was anything other than sexual pleasure was dispensed with" (231). Describing Elvis as "burlesque" seemed to be coded language for the fear that Elvis' performances might similarly be appealing to the scopic desire and sexual pleasure of white middle class teenage girls, thus disrupting the bourgeois gender order of 
middle class America in the 1950 s with a sexually role-reversed act from lower class culture.

The pervasive image of Elvis was at odds with the national efforts of moral authorities to control teenage sexuality. "When Presley executes his bumps and grinds, it must be remembered by the Columbia Broadcasting System that even the 12-year-old's curiosity may be overstimulated," New York Times columnist Jack Gould chastened. Gould called Elvis' televised appearances on the Ed Sullivan and Milton Berle shows a "selfish exploitation and commercialized overstimulation of youth's physical impulses" and "a gross national disservice." The rationality of Gould's (1956) paternalistic complaint seemed sound, as he concluded, "The issue is not one of censorship, which solves nothing; it is of common sense" (X13). Thus, the empowerment of female rock and roll fans was subtly linked to fears of sexual delinquency, a crime based on the age of the participant, and a crime rarely invoked against teenage boys, who were often encouraged to "score."

Instances that would have seemed rather innocent in Sinatra's bobbysoxer days became cause for concern in the context of a working-class rock and roll singer in the $1950 \mathrm{~s}$. The prevailing sentiment seemed to be that middle class teenage girls had overstepped the boundary of bourgeois common sense, as their energetic reaction to Elvis was cast in terms that suggested aggressive female sexuality. Indeed, at times the crowds of teenage girls seemed to overwhelm even Elvis himself. A 1956 report from a Miami concert reported that "as Elvis Presley charges to the edge of the stage to howl 'You Ain't Nothin' But A Hound Dog' screaming Miami girls charge the stage and clutch for his clothes" ("Elvis" 1956, 101). In San Diego, "the Shore Patrol was called out to save him from an overenthusiastic audience" ("Howling" 1956, 64). In Jacksonville in 1956, a "line of uniformed cops and shore patrol seated in the orchestra pit were there to keep the audience from storming over the footlights when Elvis sang his Hound Dog finale" ("Elvis" 1956, 108). Life further reported that when Presley played in Jacksonville the previous summer (1955), "his easily aroused fans ripped nearly all his clothes off" ("Elvis" 1956, 108). At another 1956 show, the mostly female teenage fans of Elvis "kicked through a plateglass door in Amarillo to get him to autograph their arms and underclothes" ("Howling" 1956, 64). After a 1957 show in Detroit, fans "piled up behind police barricades about 1,000 strong and threatened to trample the police and each other in an effort to get to Presley's dressing room" (Fislayson 1957, 132).

Other reports hinted at the disruption of normal gender relations. After a Tacoma, Washington show, "girls, dragging unwilling boys by the hand, rushed to the spot where Elvis vaulted into the car. They scooped up the durt [sic], kissed it and poured it into pockets and purses" (Duncan 1957, 171). In Toledo, Ohio, a young man threw a punch at Presley in a restaurant because of anguish that his estranged wife carried Elvis' photo, but not his, in her wallet ("Punch" 1956). 
Lisa Lewis describes fans as "highly interested, active textual participants, (who) create self-proclaimed interpretive communities and define their activities in relation to specific texts" $(1990,149)$. Elvis, then, was not a force that corrupted young women, but a text that could be used to negotiate the stultifying sexual repression of society and the desire for sexual pleasure and freedom that could brand one as a "bad girl." Concertgoing girls in the mid-1950s arrived at evening shows with dress suggesting the well-mannered comportment of adult women. According to Elvis biographer Albert Goldman (1981),

In the evening, the average age is thirteen and the proportion of females may run as high as ninety percent. . . . It would have been unthinkable for any properly brought up child to appear at a theater or auditorium wearing pedal pushers or short shorts or jeans and a $T$-shirt. ... These junior misses wear long billowing skirts over crinolines or tight sheaths and chemises (cocktail dresses) over even tighter girdles and nylons. They curl and spray their short hair. They apply pancake, lipstick, liner and nail polish. They bedeck themselves with earrings, bangles, and charm bracelets (including always the gold calendar leaf with their birthstone). They jiggle on heels. Some of them are even wearing white gloves. If they are going steady, they wear their boyfriends' rings on chains around their necks. The other appurtenance with which they come equipped is a Brownie camera with a flash attachment. (188-89)

Thus, the girls embodied the middle class propriety that would be expected of them on a formal evening date. Yet, empowered by the community of similar-minded fans crammed in a local theater and released from the rituals and sexual pressures of a real date, the female fans could explore sexualities that deviated from the dominant social script. Goldman (1981) described Elvis' strange appeal:

Elvis was the flip side of (the) clean-cut conventional male image. . . God! what a freak the boy must have looked to those little girls peering at him through their camera finders. And what a turn-on! Typical comments were: "I like him because he looks so mean"; "He's fascinating-like a snake"; "I hear he peddles dope"; "He's been in and out of jail"; "He's gonna die of cancer in six months." (191)

Through their activities as fans, they could subvert the veneer of prudent and predictable sexuality and vicariously experiment with the mysteries and pleasures of sexual taboos that might be wrapped up in the persona of Elvis. Ehrenreich, Hess, and Jacobs (1986) explain "Rock 'n' roll offered a new vision of sexuality (female as well as male) that was distinctly undomesticated; and it offered an unprecedented vision of men, not as beaux or breadwinners but as sex objects for women" (6-7).

In addition, as the loud and sometimes audacious fans, teenage girls had themselves become the subjects of rock and roll. They created a uniquely powerful position: makers and keepers of Elvis (and other early rock and roll stars). In the words of Ehrenreich, Hess, and Jacobs (1986), behind Elvis' tough, working-class exterior, "he was really vulnerable, and would be back behind the stick shift of a Mack truck if you, the fans, 
hadn't redeemed him with your love" (33). Sue Wise (1990) found a similar function for Elvis in her lonely years as an adolescent. "He was a way of being acceptably 'different' because it simply wasn't fashionable to be an Elvis fan when I was one. . . . He was someone to care about, to be interested in, and to defend against criticism" (395).

An article entitled "The Girls in Presley's Life" in the February 1957 edition of Complete TV magazine, one of a number of publications covering the lives of early television stars, presented several fan mail excerpts from young women across the country who are "Elvis' girls" (Little, 1957). The article negotiates the subject of Elvis by playing to the pleasures of the young female fans (with the revealing thoughts of like-minded fans, plus seven large photos of Elvis and a cover page photo), yet providing double-coded criticism of the behavior of Elvis' girls that could be both reassuring to older readers and ironically funny to young female Elvis fans. Even if the letters themselves are not entirely authentic (a possibility: they could have been fictional composites embellished by the writer), they do provide an excellent illustration of the prefeminist discourse about Elvis in the realm of popular culture.

One letter, by "Marie," reads:

Though I am only 14 years old I feel like a woman. I feel and what I feel is the excitement of Elvis. The excitement of his crazy and gorgeous music. That's alive music! That's sending music! That's heaven music. I feel so grown up when I listen to Elvis Presley. He's the end. If I could meet him face-to-face I'd say to him: I love you Elvis. My name is Marie. And don't think because I'm only 14 years old that I don't know anything about love. I do. I do. When a girl will die for you, isn't that love? Just like Juliet in 'Romeo and Juliet.' (Little 1957, 58)

The writer comments that "Sure, Marie has the body and feelings of a woman. How else [to] explain her earthy lust. Doesn't the thought give you the shivers?" (58).

Another letter, by "Lana," says:

I just had a fight with my boy friend because of Elvis Presley. Jealous, that's why. Jimmy's jealous of Elvis. Simply can't stand him because he's handsome, rich, successful, famous. Jimmy's a slob. All he can do is work in a butcher shop. Too tired at night to bounce to the beat. Slob, that's what he is. And he tried to tell me I was a juvenile delinquent just because I jump out of my skin whenever I see and hear Elvis. What a slob Jimmy is and I hope he drops dead. He's dead now but he doesn't know it. I'm going to find me a man who looks and sounds and thinks like Elvis. I need him. I don't know how much longer I can go on without him. I just don't know. (Little 1957, 58)

The Complete TV writer comments: "Yesterday (Lana) was such a nice, sensible kid. Just thinking about her Jimmy thrilled her to pieces, but today Jimmy is a slob. He likes quiet music, quiet dancing. His body doesn't jump as high as the sky. Higher. Poor Lana and her unrequited love" (58).

Finally, "Vera," who identifies herself as a college graduate and a pretty good student, writes: 
I dig Elvis and his music. It was made and created for people like us. What's wrong with making your body take up the beat of the rhythm? And why put so much shame on people giving vent to pent-up emotions! It's about time music was played to awaken people to the presence of their bodies, their minds. Rock and roll is wake-up music. And Elvis Presley is a wake-up man. . . Elvis helped me to get rid of my inhibitions. What a prude I was. To think of all those wasted years! I'll never hold my body rigid again when I dance. I'm going to let myself go, go, go ... all the way. (Little 1957, 58)

In this case, the writer responds "Well, Vera, what can I say? But I would like to caution you a moment. It's nice to get rid of inhibitions. I approve. But it's also a good idea to hold on to your hat. Don't go all the way. You'll like yourself better in the morning. Honest you will" (58). The writer concludes by accusing the letter-writers of lascivious gutter talk, but then adds "it's not entirely their fault that they claw, scream, swoon . . . they'll get over it. The nice Jimmys and Johnnys and Dicks will come into favor again. Don't worry, moms and dads, your Judys and Janes will come back to earth . . . soon, I hope" (58).

A whole decade before the rise of the radical feminist movement, young women's status in early rock and roll upset the prevailing sexist gender order, which consisted of an entire "social system - embedded in law, tradition, economics, education, organized religion, science, language, the mass media, sexual morality, child rearing, the domestic division of labor, and everyday social interaction - whose intent and effect was to give power to men over women" (Willis 1989, xiii). The threat to the sexist social system was real, and an ideological countermovement to coopt rock and roll for the traditional gender order worked swiftly. Elvis was soon transformed, Chuck Berry and Jerry Lee Lewis were discredited, and dozens of new, acceptable performers flooded the rock and roll scene.

\section{Repairing the Gender Order, Reformulating Rock and Roll}

The irony of the sexual double standards of the 1950s were not lost on all. John Shamik (1956), in an article in House \& Garden magazine, compared boys' responses to Marilyn Monroe and girls' responses to Elvis to illustrate what was becoming a gender double standard. "Somehow we accept with amused tolerance the whistles and mutterings of the boys, including a good many boys of rather advanced age. But the squeals of the girls embarrass us, and, in the context of the controversy over Rock 'n' Roll, we are frightened of what we imagine to be the consequences" (40).

Of course, the imagined, but never-stated consequences were that white, middle class teenage girls were on the verge of becoming sexual delinquents, en masse. If these girls had become too powerful, and rejected the social rules of courtship and marriage, their futures wouldn't be sewn up in domestic bliss and consumer consistency, as they should be. 
The insubordinate elements of Elvis-his style of dress, his long hair, his music, his regionalisms-were all mollified by his induction into the Army in 1958, which some say came as a result of a conspiracy to draft Elvis. With Elvis' career and physical presence circumscribed by the U.S. government, a number of other performers were prepared to fill the gap. But several important-and mostly exaggerated-instances served as rallying points for maintaining order by symbolizing bourgeois fears about the black men and hillbilly whites who had become rock and roll idols for white, middle class teenage girls.

In the first instance, a travelling rock and roll revue hosted by pioneer rock and roll deejay Alan Freed on May 3, 1958 at the Boston Arena turned into a riot, resulting in injuries, and an indictment for Freed. The start of the riot was rather ironic, since it was likely incited by overbearing Boston police at the racially integrated show. According to one account, "apparently a vocal group was on stage and a white girl rushed the stage in a frenzy, jumped to the lip of the stage, and grabbed a black singer by the genitals. A Boston policeman saw this and flipped out, pushing his way forward and wading into the crowd, which panicked. Seeing this, and fearing the worst, the rest of the security forces moved in, and the crowd was driven out of the auditorium into the streets" (Ward, et al. 1986, 176). The incident confirmed many people's suspicions about the music's inflammatory effects, and led to a spate of East Coast municipalities banning public rock and roll shows.

In the second instance, Jerry Lee Lewis was on tour in England in May, 1958 with his new (and third) wife Myra. British reporters soon discovered that Myra, the bride of the 22-year-old singer, was not 15, but 13 years old, and-it was later revealed—was also his cousin ("Jerry Lee Lewis" 1958). Other reports suggested that Lewis wasn't exactly divorced from his previous wife either. Back in the United States, Lewis' reputation and career were doomed. Although middle class women of the $1950 \mathrm{~s} \mathrm{mar-}$ ried at a younger age than any other time in the twentieth century, Lewis' bride suggested hillbilly rock and rollers were incorrigible cradle-robbers, and moreover, stereotypically incestuous.

Finally, black rock and roll star Chuck Berry was also charged with corrupting young white women. On August 28, 1959, Berry, then 23, was arrested for "trying to date a Mississippi white girl" ("Negro singer" 1959, 38). In the next year, Berry was subject to three trials for charges that he was in violation of the Mann Act, which outlaws the transportation of a minor across state lines for immoral purposes (Berry 1987; Martin and Seagrave 1988). Berry won the first case, which involved a young white French woman. The other cases involved an Apache girl, reportedly a 14 year-old prostitute. The first decision was thrown out because the judge had been so overtly racist, but Berry lost the retrial, and served nearly two years in jail. Cognizant of the " 'terrible things' that could happen to a black who was 'seen as sexually attractive to white women,"' Little Richard, another black rock and roll star of the 1950 s, said that he intentionally 
created his eccentric, effeminate persona in order to appear non-threatening (Martin and Seagrave 1988, 73).

As soon as rock and roll arrived on the doorstep of bourgeois America, efforts were underway to reformulate the idiom and iron-out disruptions of the social order. True to Stuart Hall's (1981) dictum, "The meaning of a cultural form and its place or position in the cultural field is not inscribed inside its form" (235). Thus, rock and roll-known to at least one "noted psychiatrist" as a "communicable disease" ("Rock-and-roll" 1956, L33)was reformulated in the vision of bourgeois morality, complete with young, white, middle class performers. Popularizing (with the help of record companies and mass media outlets) white cover versions of black rock and roll songs, Pat Boone became the most notable of the "safe" performers.

Pat Boone illustrated the ordinative possibilities of rock and roll. The whiteness of Boone was apparent in his cover versions of Fats Domino and Little Richard songs. Unlike Presley, Boone didn't try to approximate black performers in dress or vocal style, but instead mildly crooned his versions of such raucous hits as "Ain't that a Shame" and "Tutti Frutti." His biggest hit, "Love Letters in the Sand," was first popularized by fellow crooner Rudy Vallee. The class standing of Boone was also ordinative. Newsweek noted that "unlike most entertainers whose childhood is beset with stresses and strains, Pat grew up in a household of impeccable normality." Normal, in this case, was a building contractor father, a mother who was both a doting housewife and registered nurse, and a family lineage descending directly from frontiersman Daniel Boone ("Pat Boone-soaring" 1957). No generation gap was evident in Boone's life. By his early twenties, "Pat managed to captain his high school baseball team, marry his boyhood sweetheart, father four daughters and graduate from Columbia magna cum laude" ("Pat Boone boom" 1957, 75). His "normality" was rewarded with several hit records, a Chevrolet-sponsored television show, and a long-term movie contract.

A 1957 Newsweek cover of Boone captured the adult sentiment about Boone. At the top of the cover, a headline read "Why boys kill-why we can't control them: Our juvenile jungles." At the bottom of the page, beneath pictures of a smiling, guitar-strumming Boone and a serious, pensive Boone, the caption read: "Pat Boone: His refreshing song fills the air." Thus, Pat Boone served as an antidote for the ills of juveniles, and provided a proper path for middle class life. In his popular 1958 book, 'Twixt Twelve and Twenty, Boone expounded on spiritual growth, education, the value of work and a savings account, and respect for parents. Boone's cautionary and puritanical suggestions on kissing could be writ large to adhere to the prevailing attitudes on sex and women's virginity as a valued commodity.

It's not a game. Believe me! . . Kissing for fun is like playing with a beauti- 
thing - when it ceases to be rare, it loses its value. ... I really think it's better to amuse ourselves in some other way. ... I say go bowling, or to a basketball game. ("Pat Boone boom" 1957, 80)

Boone's mostly young, white, middle-class female fans responded much like Sinatra's bobby-soxers had in the previous generation: in Boone they had found an attractive, readily-available (via the mass media) sexual object, but without the complications of race, class, or generational differences. With the emergence of Boone, battle over the existence of rock and roll as a cultural form had ended: rock and roll was here to stay. The new battles about rock and roll would be over meaning: would rock and roll be redirected to represent an ordinative discourse, still appealing to young people's sexuality, but in an acceptable, traditional context? Or would rock and roll still offer texts that could shake-up the gender order and appeal to young women searching for a new vision of sexuality?

A number of new, well-publicized performers in the late 1950s and early 1960s joined Pat Boone's chorus of ordinative rock and roll discourse. Ricky Nelson, the white, middle-class teenage star of television's family sitcom The Adventures of Ozzie and Harriet, recorded Fats Domino's "I'm Walkin" and launched a career as a teen idol. Even as a singing star with hordes of teenage female fans, Nelson maintained a perfect middle-class persona; Life reported that although Nelson accumulated several hundred thousands of dollars, he put the money in a trust fund, and lived on an allowance of ten dollars a week from his father ("Teen-ager" 1958).

Perhaps the center of well-regulated, ordinative rock and roll was disc jockey Dick Clark, via his role as host and producer of American Bandstand, a Philadelphia-based show that began network broadcasts on $A B C$ in 1957. The show featured local teenagers dancing to and rating rock and roll songs, with a watchful eye on norms of middle-class propriety: Clark's rules included "no smoking, no tight sweaters or dresses, no slacks, no hats or overcoats, no gum-chewing," plus neckties and jackets or sweaters for the men ("Challenging" 1957, 70). Also important were the show's informal rules: the studio teenage audience was all white, and most performers were as well. Clark himself-described by Newsweek as "clean-cut, unobtrusive"-was the symbolically safe, white, middle-class purveyor of rock and roll, a position that helped him survive the Congressional investigations in the payola scandal of 1960.

Clark introduced teenagers to a number of new performers, including Frankie Avalon, Fabian, Bobby Vee, Bobby Rydell, Neil Sedaka, Paul Anka, Chubby Checker-and some of the era's first female stars: Connie Francis, Brenda Lee, and the Shirelles. The early 1960 s also brought a number of other female performers-most of them black- to the forefront of rock and roll with an "uptown rhythm and blues sound" (Hibbard 1983,

66 24). The Crystals, Ronnettes, Marvellettes, Chiffons, Shangri-Las, Supremes, and Martha and the Vandellas are some of the most notable of these "girl groups." 
The new crop of male performers typically carried a message of ordinative gender discourse, but many of the emerging girl groups offered female fans a fresh text for transgressive discourse. Whereas Elvis and other early male rock and roll stars permitted young women to question the sexual repressiveness of being a good girl, girl groups provided opportunities for young women to realize their subordination in a relationship with any man, whether he was a conforming crew-cut or a tough-guy greaser. The Shirelles' 1960-61 hit "Will You Love Me Tomorrow," and Lesley Gore's 1964 hit "You Don't Own Me" illustrate some of the prefeminist possibilities in girl group songs. As Susan Douglas (1993) notes, by the early $1960 \mathrm{~s}$, a distinctive teen girl culture had emerged. The young female performers "sang about the pull between the need to conform and the often overwhelming desire to rebel, about the tension between restraint and freedom, and about the rewards—and the costs-of prevailing gender roles" (352).

Unfortunately, most critical authorities discount the impact of the girl groups of the early 1960s (as they had discounted female rock and roll audiences of the 1950s). The period highlighted by the mild rock and roll crooners, girl groups, and the vocal harmonizing of the urban rhythm and blues sound - roughly from 1959 to 1963 - is often treated monolithically and regarded by critics as rock and roll's most mediocre period. For example, Mike Jahn, a rock critic for the New York Times, wrote that "The female vocal group of the early $1960 \mathrm{~s}$ served to drive the concept of art completely away from rock ' $n$ ' roll ... I feel this genre represents the low point in the history of rock ' $n$ ' roll ..." (Ward, et al. 1986, 275).

Similarly, rock historian Don Hibbard $(1983,24)$ decreed that the uptown rhythm and blues sound was inferior to the work of male rock and rollers such as Elvis, Chuck Berry, and Little Richard. The downfall of uptown R \& B was its "mawkish harmonic webs of romance and heartache," Hibbard stated. "Rather than presenting an immediate emotional response, they struck postures and elicited superficial sentiment."

The British Invasion of 1964 rescued American rock and roll from such romantic mediocrity, these type of historical accounts generally conclude. The Beatles initiated a fan outburst—Beatlemania-surpassing even Elvis' and Frank Sinatra's early days, and presented a richly anti-authoritarian persona symbolized by their long, mop-top hair, and irreverent wit. According to Ehrenreich, Hess, and Jacobs (1986), the sexual appeal of the Beatles for their audience of mostly young girls was their androgyny and playful approach to sexuality. "Theirs was a vision of sexuality freed from the shadow of gender inequality because the group mocked the gender distinctions that bifurcated the American landscape into 'his' and 'hers'" (35; see also Pratt 1979, 47).

Although rock and roll still existed as a "teenager's sanctuary from the adult world," as Jann Wenner later called it, it wasn't automatically a place for sanctuary from the commonly accepted gender roles. Early rock and roll had largely blocked women from a performance role, yet young 
women maintained a predominant role as powerful subjects of rock and roll through their vigorous fandom. By the mid-1960s, definitions of rock and roll began to change, so that its essential qualities were coded in terms of aggressive male sexuality, while androgynous, romantic rock and rollmost often the domain of young women-was increasingly marginalized. Women were left to attend to music that was not real rock and roll (e.g., teenybopper music), or they could participate in aggressive male rock and roll only as its objects.

The Rolling Stones were innovators in this new kind of sexually dominant, masculine rock and roll. The Stones were originally just another long-haired band in the British Invasion, hoping to become Beatles-like teen idols by dressing in matching suits and singing cover versions of American rhythm and blues songs. Only mildly successful, the Rolling Stones' manager formed a new image for his band, making them the raunchy alternative to the spirited Beatles (Szatmary 1987; Hibbard 1986). The lascivious Rolling Stones offered an ambiguous discourse, transgressing all notions of sexual containment in courtship and marriage, but conversely maintaining the sexual order of male dominance. In the discourse of the Rolling Stones, men dominated the arena of liberated sex, as they had dominated the arena of marriage. Where the Beatles had expanded the possibilities for young women, the Rolling Stones offered them a new sexuality that was ultimately as limiting as status quo.

Typical of the reinvented Stones was their 1966 hit "Under My Thumb," which, according to Hibbard (1983), "added another dimension to the Stones' sexual image. Laced with (lead singer Mick) Jagger's sexual asides, delivered with just the right inflections, the song centered on an element of power. Jagger now controlled the girl, who once had pushed him around, and he relished the fact and gloried in this sense of power" (91). A 1967 album, Between the Buttons, extended the Stones' ideology. Hibbard (1983) argues that the album's songs "depicted women as objects, and handled them in a ruthless, impersonal manner. Discarding one as no longer current and pursuing the other as a possession, the Stones' 'badness' now came forth in their heartless execution of social values" (92).

The Beatles, too, had begun to change their appeal. By 1966, the Beatles had given up live concerts for the studio, and-with inspiration from politically relevant folk rocker Bob Dylan-had hegun "a major shift away from the group's consuming focus on romantic love" with their $R u b$ ber Soul album (Ward, et al. 1986, 315). As rock and roll fans now included an older contingent in their twenties, and as the music became both socially conscious and sexually misogynistic, songs addressing the concerns of preteen and adolescent girls became increasingly peripheral, while the new directions in music were deemed more "serious." 


\section{Institutionalizing the Gender Order of Rock and Roll}

The boundaries of rock and roll have never been clear, as it seems to have appropriated nearly every type of musical style to some degree. According to Lawrence Grossberg, mapping the boundaries of rock and roll is part of everyone's process of making sense of the music. What's most relevant to this process, he argues, is deciding what qualifies to be called rock and roll. Grossberg (1992) explains that "At every moment in rock's history, people have identified some musics, audiences or alliances as inauthentic. These are dismissed, not merely as bad or inferior rock, but as mere entertainment, as not really rock at all" (207).

Mapping the boundaries of rock and roll is not only an individual activity, but can also be engaged on a social level. At this level, via the institutions and authorities of rock and roll criticism in the late 1950s and 1960 s, from public officials to recording industry executives to the selfdescribed official publications of rock and roll, the power of ordination became enacted on a culture-wide basis. Since the late 1950s, women's experiences as fans (and later as performers) of rock and roll have often been dismissed, limited, or marginalized. Music that has been popular with young women has been typically defined as not art but "superficial sentiment," not rock and roll, but "mere entertainment" and "teenybopper" fare.

The organizational structure of the rock and roll music industry changed in the 1960s, further excluding the young female audience from the evolving boundaries of "real" rock and roll. As generational divisions beset the aging rock audience for the first time in the 1960s, the deregulation of FM radio provided an outlet for free-form album-oriented rock formats, an alternative to tight Top 40 playlists that typified AM radio. Additionally, rock and roll criticism became institutionalized, first with fanzines such as Crawdaddy in 1964, and more formally with the debut of Rolling Stone in 1967. Like radio playlists, rock and roll criticism has played a major role in mapping rock and roll boundaries for America. It quickly became apparent that most rock critics seemed to have a good idea what qualified as "rock and roll," and it didn't include teenybopper bands. R. Serge Denisoff (1975) noted that by 1967, "critics no longer spoke for a monolithic body of fans as they had during the days of Beatlemania," but instead either ignored or disparaged the "so-called teenybop bands like Blue Cheer and Strawberry Alarm Clock" and the Monkees (305).

In the male dominated business of rock and roll criticism-which is "more overwhelmingly male than rock itself" according to critic Karen Durbin (McDonnell 1992,18) -it is commonplace to celebrate young sexy women in music and videos, and harshly criticize the sexuality and talent of cute, androgynous young men. Former New York Times rock critic Karen Schoemer explains that bands with "cute" male leads who attract mobs of admiring teenage girls are shunned by the mainstream rock establishment. "A lot of male critics automatically take that as saying that 
a band is not serious," she explains (McDonnell 1992, 19). This critical perspective was further rationalized in FM band AOR (album oriented rock) radio formats that arose in the 1970s, which featured rock music played primarily by white, male musicians, "emphasizing prominent guitar hooks and matter-of-fact sexism: dominance (emotional, sexual, aesthetic, marketplace) was all" (Ward et al. 1986, 484). Although some women found this music appealing, the target audience was males, ages 13-25. This same format governed the content of MTV when it originated on cable television in the early 1980s. Disco music, which emerged in the 1970s as an alternative to the sexist, racist, and homophobic exclusions of AOR, was also vehemently condemned by the male rock and roll establishment in a sometimes violent anti-disco crusade (Ward, et al. 1986).

As fans, young women were important consumers of rock and roll music, yet stereotyped as emotional, maniacal screamers, whereas men were considered to be a more knowledgeable and "serious" rock and roll audience. Nevertheless, the marginalized "teenybopper" or "bubblegum" music of the 1970s could be just as empowering as the experiences that earlier fans had with Elvis or the Beatles. Sheryl Garratt (1990) described this same type of subordinate inversion of gender power in her experience as a fan during the meteoric rise (and fall) of the androgynously cute Bay City Rollers in 1975:

We were a gang of girls having fun together, able to identify each other by tartan scarves and badges. Women are in the minority on demonstrations, in union meetings, or in the crowd at football matches: at concerts, many were experiencing mass power for the first and last time. Looking back now, I hardly remember the gigs themselves, the songs, or even what the Rollers looked like ... Our real obsession was with ourselves; in the end, the actual men behind the posters had very little to do with it all. (401-02)

Of course, by the time of the Bay City Rollers, girls' rock and roll experiences were rarely validated outside of the specific audience. Garratt (1990) notes that "most of us scream ourselves silly at a concert at least once, although many refuse to admit it later, because like a lot of female experience, our teen infatuations have been trivialized, dismissed, and so silenced" (400).

\section{Conclusion}

Rock and roll, then, initially offered a site where subordinative discourses regarding such issues as race, class, age, and gender could take place. In the case of gender, young women - at least white, middle-class girlstransgressed the social order of gender by becoming worthy subjects of rock and roll in their own right, through their collective power as fans. Being a fan of early rock and roll provided the possibility of subversive and prefeminist alternatives to young women in the 1950 s and 60 s who were otherwise destined for a life of teenage sexual propriety, followed by a life 
as a mother and domesticated consumer. The music industry responded to complaints of traditional social authorities by offering trangressive youth (especially girls) rock and roll performers who spoke a more ordinative discourse. Many girl groups and uptown R \& B groups of the early 1960s, however, still offered a potentially subordinative discourse to girls willing to question the gender order of the day.

By the mid-1960s - after Beatlemania provided more potentially transgressive subjects for young women-rock and roll critics, radio, and the music industry routinely celebrated rock music's role as an aggressive assertion of teenage identity. But in this case, the celebrated subordinative possibilities were mainly available to males. Through the subsequent accretion of rock and roll texts, authentic rock and roll seemed to be an essentially masculine form of music. Thus, Frith and McRobbies's original characterizations of "cock rock" and "teenybop" communicate a naturalized commonsense gender order in rock and roll.

Of course, there have been transgressions of rock and roll's own seemingly seamless gendered nature. Janis Joplin, a white singer from Texas who reformulated the styles of 1920 s African-American blues singers such as Bessie Smith, offered an untraditionally powerful female sexual persona in her short-lived career based in San Francisco in the late 1960s. In the 1980s and 1990s, Madonna has been both condemned and praised for her chameleon-like identity as both a boy-toy sex object, and as a women in control of her sexuality. The riot grrrl punk rock bands in the early 1990s and female performers/songwriters such as PJ Harvey and Liz Phair have also advanced the "female/feminine/feminist" subject to both "gain pleasure and power as an aggressive woman stepping outside the expected behavior" and to exaggerate expected behavior "until it becomes something else" (Powers 1994, 12). The androgyny of Michael Jackson, Prince, David Bowie, Robert Smith of The Cure, and other male performers transgresses the essentialized masculinity of rock and roll, and complicates the simplicity of the cock rock/teenybop dichotomy.

For all of the transgressions of the rock and roll industry's masculine gender order, though, the order itself is largely intact. Although a new feminist sensibility has entered the rock industry, it is usually cast in terms of novelty, and presented as something that needs to be understood and evaluated from the perspective of a masculine rock and roll tradition. Through this perspective, women in rock and roll are often classified as outside the norms of rock and roll, or only representing female interests. Ironically, as rock and roll marginalizes women, the outsider status-in the context of rock and roll's mythology of rebellion-can be a source of empowerment. Conversely, as society's masculine gender system has become institutionalized in rock and roll, masculinized rock has relinquished any possibility of taking up an insubordinate position against the social gender order. Because the pleasures of rock and roll are in its power to reject all that is boring, normal, and controlling (Grossberg 1992), rock 
and roll surrendered the opportunities and pleasures of gender power transgression to feminist and gay politics.

However, given the history of rupture and repair in the social order of gender, it is not surprising to see the emergence of another discourse that reconfigures the traditional masculine gender order of rock and roll as transgressive. The aim of this backlash discourse is to make feminism seem normal, boring, and controlling. In doing so, feminist discourse in rock and roll is once again defined as outside of the realm of transgressive rock and roll pleasure, and once again is marginalized.

\section{Department of Communication}

University of Michigan

\section{NOTES}

An earlier version of the paper was presented to the Qualitative Studies Division of the Association for Education in Journalism and Mass Communication (AEJMC) Conference in Atlanta, Georgia, August 1994. I would like to thank Bettina Fabos for helpful comments on earlier drafts of this manuscript, and Mary Ann Flora for her personal insights as a Frank Sinatra bobby-soxer.

${ }^{1}$ According to Gilbert, this national fear of juvenile crime peaked from 1953 to 1956. Youth-oriented mass media, such as rock and roll music, films like The Wild One, Blackboard Jungle, and Rebel Without a Cause, and the popular crime comic books were all demonized as corrupting agents of juveniles.

${ }^{2}$ The Paramount was later the New York location for Alan Freed's groundbreaking rock and roll shows in the 1950s.

${ }^{3}$ See Gilbert $(1986,30-33)$ for a discussion of the subversive coding of the zoot suit.

\section{REFERENCES}

Allen, Robert. 1991. Horrible prettiness: Burlesque and American culture. Chapel Hill: University of North Carolina Press

Baxter, James and Annette Baxter. 1958. The man in the blue suede shoes, Harper's, January, 45-47.

Berry, Chuck. 1987. Chuck Berry: The autobiography. New York: Harmony Books.

Bliven, Bruce. 1945. The Voice and the kids. Reader's Digest, January, 12-14.

Blumer, Herbert and Philip M. Hauser. 1933. Movies, delinquency, and crime. New York: Macmillan.

Carby, Hazel V. 1990. "It just be's dat way sometime": The sexual politics of women's blues, In Unequal sisters: A multicultural reader in U.S. women's history, eds., Ellen Carol DuBois and Vicki L. Ruiz, 238-249. New York: Routledge, Chapman \& Hall.

Challenging the giants. 1957. Newsweek, 23 December, 70.

Christenson, Peter G. and Jon Brian Peterson. 1988. Genre and gender in the structure of music preferences. Communication Research 15(3): 282-301. nostalgia trap. New York: Basic Books. 
Denisoff, R. Serge. 1975. Solid gold: The popular record industry. New Brunswick, N.J.: Transaction Books.

Douglas, Susan J. 1993. Will you love me tomorrow? Changing discourses about female sexuality in the mass media, 1960-1968. In Ruthless criticism: New perspectives in U.S. communication history, eds., William S. Solomon and Robert W. McChesney, 349-373. Minneapolis: University of Minnesota Press.

The dreamy teen-age market: "It's neat to spend." 1957. Newsweek, 16 September, 94.

Duncan, Don. 1957. Presley rocks 'n rolls Tacoma teenagers into frenzy at bowl. Tacoma News Tribune, 2 September. [Quoted in Rijff, Ger. 1987. Long lonely highway: A 1950's Elvis scrapbook, 168-173. Ann Arbor: Pierian Press.]

Ehrenreich, Barbara, Elizabeth Hess, and Gloria Jacobs. 1986. Re-making love: The feminization of sex. New York: Anchor.

Elvis - a different kind of idol: Presley's impact piles up fans, fads-and fears. 1956. Life, 27 August, 101-109.

Fislayson, John. 1957. Elvis wiggles and wails as 24,000 scream and sob. Detroit Free Press, 1 April. [Quoted in Rijff, Ger. 1987. Long lonely highway: A 1950's Elvis scrapbook, 168-173. Ann Arbor: Pierian Press.]

Frazier, George. 1943. Frank Sinatra: "Bedroom singer" from Hoboken rose from 70 cents to $\$ 2,500$ a week through voice that makes women swoon. Life, 3 May, 55-62.

Friedan, Betty. 1963. The feminine mystique. New York: W.W. Norton.

Frith, Simon. 1990. Afterthoughts. In On record, eds., Simon Frith and Andrew Goodwin, 419-424. New York: Pantheon.

Frith, Simon and Angela McRobbie. 1990. Rock and sexuality. In On record, eds., S. Frith and A. Goodwin, 371-389. New York: Pantheon.

Garratt, Sheryl. 1990. Teenage Dreams. In On record, eds., Simon Frith and Andrew Goodwin, 399-409. New York: Pantheon.

Gilbert, James. 1986. A cycle of outrage: America's reaction to the juvenile delinquent in the 1950s. New York: Oxford University Press.

Goldman, Albert. 1981. Elvis. New York: McGraw-Hill.

Gould, Jack. 1956. Elvis Presley: Lack of responsibility is shown by TV in exploiting teen-agers. New York Times, 16 September, X13.

Grossberg, Lawrence. 1992. We gotta get out of this place. New York: Routledge.

Hall, Stuart. 1981. Notes on deconstructing "the popular." In People's history and socialist theory, ed. Raphael Samuel, 227-240. London: Routledge \& Kegan Paul.

Haralovich, Mary Beth. 1992. Sit-coms and suburbs: Positioning the 1950s homemaker. In Private Screenings, eds., Lynn Spigel and Denise Mann, 111141. Minneapolis: University of Minnesota Press.

Hibbard, Don J. 1983. The role of rock. Englewood Cliffs, N.J.: Prentice-Hall.

A howling hillbilly success: Young Elvis Presley's complaint becomes nation's top pop tune. 1956. Life, 30 April, 64.

Jerry Lee Lewis' tour off. 1958. New York Times, 28 May, 36.

Laufer, Charles. 1957. Hello! from the editor's desk. 'Teen, June, 5.

Lewis, Lisa. 1990. Gender politics and MTV: Voicing the difference.

Philadelphia: Temple University Press.

Lipsitz, George. 1990. Time passages: Collective memory and American popular culture. Minneapolis: University of Minnesota Press.

Little, Bessie. 1957. The girls in Presley's life. Complete TV, February, 14-16, 58.

The luckiest generation. 1954. Life, 4 January, 27-29.

Martin, Linda and Kerry Seagrave. 1988. Anti-rock: The opposition to rock ' $n$ ' roll. Hamden, CT: Archon Books. 
Masters, Bob. 1956. Frenzied Elvis fans rock youth center. Shreveport Times, 16 December. [Quoted in Rijff, Ger. 1987. Long lonely highway: A 1950's Elvis scrapbook, 116-118. Ann Arbor: Pierian Press.]

May, Elaine Tyler. 1988. Homeward bound: American families in the cold war era. New York: Basic Books.

McDonnell, Evelyn. 1992. The feminine critique: The secret history of women and rock journalism. Village Voice Rock \& Roll Quarterly, Fall, 18.

Miller, Douglas T. and Marion Nowak. 1977. The Fifties: The way we really were. Garden City: Doubleday.

Negro singer jailed: Accused of trying to date Mississippi white girl. 1959. New York Times, 29 August, 38.

A new, \$10-billion power: the U.S. teen-age consumer. 1959. Life, 31 August, 7885.

Pat Boone boom. 1957. Life, 2 February, 75.

Pat Boone-soaring on a song. 1957. Newsweek, 19 August, 52-55.

Powers, Ann. 1994. Become what you are. Village Voice Pazz \& Jop, 1 March, 12.

Pratt, Linda Ray. 1979. Elvis, or the ironies of a Southern identity. In Elvis: Images and fancies, ed. Jac L. Tharpe, 40-51. Jackson: University Press of Mississippi.

Punch misses Presley: Youth, 19, resents his wife's carrying picture of singer. 1956. New York Times, 24 November, 16.

Rock-and-roll called a "communicable disease." 1956. New York Times, 28 March, L33.

Sharnik, John. 1956. The war of the generations. House \& Garden, October, 40.

Spigel, Lynn. 1992. Installing the television set: popular discourses on television and domestic space, 1948-1955. In Private Screenings, eds., Lynn Spigel and Denise Mann, 3-38. Minneapolis: University of Minnesota Press.

Szatmary, David P. 1987. Rockin' in time: A social history of rock and roll. Englewood Cliffs, N.J.: Prentice-Hall.

Teen-ager rocks teen-agers. 1958. Life, 1 December, 123-126.

U.S. Bureau of the Census. 1975. Historical statistics of the United States, Colonial times to 1970, Bicentennial Edition, Part 2. Washington, D.C.: GPO

Wenner, Jann. 1986. Foreword to Rock of ages: The Rolling Stone history of rock and roll, by Ed Ward, Geoffrey Stokes, and Ken Tucker. New York: Rolling Stone Press.

Willis, Ellen. 1989. Foreword to Daring to be bad: Radical feminism in America, 1967-1975, by Alice Echols. Minneapolis: University of Minnesota Press.

Wise, Sue. 1990. Sexing Elvis. In On record, eds., Simon Frith and Andrew Goodwin, 390-398. New York: Pantheon. 